Author version: Estuar. Coast. Shelf Sci., vol.94; 2011; 291-298

\title{
Origin and biochemical cycling of particulate nitrogen in the Mandovi estuary
}

\author{
Loreta Fernandes \\ CSIR-National Institute of Oceanography, Dona Paula, 403 004, Goa, India
}

Corresponding author - Tel.: +91 832 2450537; Fax: +91 8322450602

E-mail address: loretaferns@gmail.com

\begin{abstract}
Mandovi estuary is a tropical estuary strongly influenced by the southwest monsoon. In order to understand, sources and fate of particulate organic nitrogen, suspended particulate matter (SPM) collected from various locations, was analyzed for particulate organic carbon (POC) and particulate organic nitrogen (PON), $\delta^{13} \mathrm{C}_{\mathrm{POC}}$, total hydrolysable amino acid enantiomers (L- and D- amino acids) concentration and composition. $\delta^{13} \mathrm{C}_{\mathrm{POC}}$ values were depleted ( -32 to $-25 \%$ ) during the monsoon and enriched (-29.6 to $-21 \%$ ) in the pre-monsoon season implying that OM was derived from terrestrial and marine sources during the former and latter season, respectively. The biological indicators such as $\mathrm{C} / \mathrm{N}$ ratio, D-amino acids, THAA yields and degradation indices (DI) indicate that the particulate organic matter (POM) was relatively more degraded during the monsoon season. Conversely, during the pre-monsoon, the biological indicators indicated the presence of relatively fresh and labile POM derived from autochthonous sources. Amino acids such as alanine, aspartic acid, leucine, serine, arginine, and threonine in monsoon and glutamic acid, glycine, valine, lysine, and isoleucine in premonsoon were relatively abundant. Presence of bacterial biomarker, D-amino acids in the SPM of the estuary during both the seasons signifies important contribution of bacteria to the estuarine detrital ON pool. Based on D-amino acid yields, bacterial OM accounted for $16-34 \%(23.0 \pm 6.7$ $\%)$ of POC and $29-75 \%(47.9 \pm 18.7 \%)$ of PON in monsoon, and $30-78 \%(50.0 \pm 15 \%)$ of POC and $34-79 \%(51.2 \pm 13.3 \%)$ of the PON in pre-monsoon in the estuary. Substantial contribution of bacterial-N to PON indicates nitrogen $(\mathrm{N})$ enrichment on terrestrial POM during the monsoon season. Transport of terrestrial POM enriched with bacterial OM to the coastal waters is expected to influence coastal productivity and ecosystem functioning during the monsoon season.
\end{abstract}

Keywords: Suspended particulate matter, Biological indicators, Amino acids, Bacteria, Diagenesis, Mandovi estuary 


\section{Introduction}

Each year rivers transport via estuaries $\sim 4 \times 10^{14} \mathrm{~g}$ of terrigenous organic carbon to continental margin (Schlesinger and Melack, 1981). Estuaries are also active sites for high biological production and heterotrophic metabolism. Biochemical and physical processes in estuaries may modify the quantities and characteristics of the organic matter (OM) delivered to the ocean. Activities of heterotrophic microorganisms exert strong influence on the amount and the composition of OM (Findlay et al., 1992; Tremblay and Benner, 2009). Therefore, estuaries are ideal sites to study the biogeochemistry of OM derived from terrigenous and marine sources.

$\mathrm{OM}$ in the estuaries and coastal waters is derived from several sources that can be divided into allochthonous and autochthonous. Moreover, OM from both sources may be degraded or transformed by various groups of microorganisms. As a result, it is difficult to unequivocally identify the sources of OM in estuarine samples (Canuel et al., 1995; Cloern et al., 2002). Despite this, there are several instances wherein $\mathrm{C} / \mathrm{N}$ ratio and $\delta^{13} \mathrm{C}_{\mathrm{POC}}$ have been employed previously to distinguish inputs and cycling of POM in rivers, estuaries, and marine systems (Zhang et al., 1997; Wu et al., 2007a; Bouillon et al., 2008). Moreover, a better understanding of the processing of OM in estuarine systems is required to identify the biogeochemical fate of $\mathrm{OM}$ as it is transported through the estuary to the coastal sea (Lee et al., 2004; Bourgoin and Tremblay, 2010).

Nitrogen is a principal limiting nutrient in marine production. Quality and source of PN determines its impact on coastal processes. Amino acids, the building blocks of proteins, are the major forms of nitrogen in both terrestrial and aquatic organisms. These compounds represent important constituents of living and dead OM. Their natural occurrence and geochemical behavior have been evaluated in several types of samples (Cowie and Hedges, 1992; Gupta and Kawahata, 2000; Vandewiele et al., 2009). The contribution of amino acids carbon to organic carbon and amino acid nitrogen to organic nitrogen and relative proportion of individual amino acids are useful diagenetic indicators (Cowie and Hedges, 1994; Dauwe and Middelburg, 1998; Dauwe et al., 1999; Keil et al., 2000; Chen et al., 2004). Amino acid composition of source organisms is relatively similar. However, upon degradation the amino acid composition undergoes marked differences. During degradation of $\mathrm{OM}$, glycine, serine and threonine are accumulated while tyrosine, phenylalanine and glutamic acid are depleted. Highly degraded, refractory OM of marine and terrestrial origin exhibits significantly different amino acid composition pattern, which reflect the different diagenetic processes involved in the formation and preservation of marine and terrestrial OM (Dittmar et al., 2001b). Amino acids are selectively utilized by heterotrophic microorganisms, which in turn contribute to the preserved OM (Ogawa et al., 2001; Tremblay and Benner, 2006). 
Such microbial contribution is especially found in nitrogen poor plant detritus by incorporation of exogenous nitrogen, termed $\mathrm{N}$-enrichment, where inorganic nitrogen can be converted into organic microbial molecules (Tremblay and Benner, 2006). Bacterial activity plays a central role in the production of uncharacterized molecules and OM preservation (Harvey and Macko, 1997; Tremblay and Benner, 2006). Quantification of microbial contribution, to the detrital OM is difficult considering highly heterogeneous and reworked nature of material. However, to estimate microbial contribution specific biomarkers such as D- amino acids are employed to identify sources and extent of degradation of OM (Hedges and Prahl, 1993; Pedersen et al., 2001; Grutters et al., 2002; Lomstein et al., 2009; Kaiser and Benner, 2008; Tremblay and Benner, 2009; Vandewiele et al., 2009; Bourgoin and Tremblay, 2010). This is because bacterial biomass is rich in D-amino acids, whereas, phytoplankton and most other primary producers contain almost exclusively L-enantiomers (Jorgensen et al., 1999).

In this study, we applied a combined tracer approach of stable carbon isotope and amino acid enantiomers to identify the major sources of PON and the bacterial contribution to $\mathrm{OM}$ in the Mandovi estuary during the monsoon and the pre-monsoon season.

\section{Materials and methods}

\subsection{Area of study}

The Mandovi estuary is a tropical, tide dominated, interstate river basin located between the Sahyadris hills and the Arabian Sea along the west coast of India (Fig. 1). The estuary is $\sim 75 \mathrm{~km}$ long and has a drainage area of about $\sim 1,895 \mathrm{sq} \mathrm{km} \mathrm{(Qasim} \mathrm{and} \mathrm{Sen} \mathrm{Gupta,} \mathrm{1981).} \mathrm{The} \mathrm{mouth} \mathrm{of} \mathrm{the}$ estuary is $3.2 \mathrm{~km}$ in width and it progressively narrows to $0.25 \mathrm{~km}$ towards the upstream end. The estuary receives $660 \mathrm{~cm} / \mathrm{yr}$ of rainfall (Shetye et al., 2007). During the southwest monsoon season (June to September) the estuary receives large amount of fresh water run-off, while the run-off is nearly absent during the dry season (October to May), and is regulated by semi- durinal tides. The residence time of water is usually of $5-6 \mathrm{~d}$ during the monsoon season and about $50 \mathrm{~d}$ during dry season (Qasim and Sen Gupta, 1981). Clay minerals such as smectite and kaolinite are abundant near the mouth and the upstream stations of the estuary, respectively. Mangroves are present on the banks of estuary. The Mandovi estuary is mostly used for navigation of fishing vessels, transport of ores and people and for recreation activities. Recently, physical, chemical and biological characteristics of the estuary have been compiled (Shetye et al., 2007).

Fig. 1 


\subsection{Sample collection}

Surface $(\sim 1 \mathrm{~m})$ water samples were collected using a 5L Niskin sampler from various locations in the estuary during the summer monsoon (August 2005), and the pre-monsoon season (March 2007) (Fig. 1). Immediately, after collection, the water was passed through $200 \mu \mathrm{m}$ mesh to remove large zooplankton, and then filtered through pre-ashed $\left(450^{\circ} \mathrm{C}, 4 \mathrm{~h}\right) \mathrm{GF} / \mathrm{F}$ filters $(47 \mathrm{~mm}, 0.7 \mu \mathrm{m}$ pore size) to collect suspended particulate matter (SPM), for the analysis of chlorophyll $a$ (Chl $a$ ), particulate organic carbon (POC) and particulate organic nitrogen $(\mathrm{PON}), \delta^{13} \mathrm{C}_{\mathrm{POC}}$, and total hydrolysable amino acids (L- and D- amino acids). After filtration, GF/F filters containing SPM were transferred into clean screw cap vials and stored at $-20{ }^{\circ} \mathrm{C}$. In order to estimate total bacterial count (TBC), seawater sample $(20 \mathrm{ml})$ was fixed with glutaraldehyde (final concentration $2 \%$ ) and stored for 7 days at $4{ }^{\circ} \mathrm{C}$ until analysis.

\subsection{Analytical methods}

\subsubsection{Hydrographic and Bulk chemical parameters}

Surface water temperature and surface salinity were measured by the portable conductivity/temperature/depth (CTD) (Model SBE 19 plus, SeaBird Electronics, USA) Instrument. The GF/F filter containing SPM was washed with $10 \mathrm{ml}$ distilled water, and the filter was dried at 60 ${ }^{\circ} \mathrm{C}$, and then weighed on a microbalance (Mettler Model AT20). SPM weight was obtained by subtracting the weight of empty $\mathrm{GF} / \mathrm{F}$ filter from the weight of $\mathrm{GF} / \mathrm{F}$ filter containing SPM. Chlorophyll $a(\mathrm{Chl} a)$ was estimated by the fluorometric method (Boto, 1978; Parsons et al., 1984). In order to estimate $\mathrm{TBC}$, a known volume of seawater $(2-5 \mathrm{ml})$ was stained with acridine orange (final concentration $0.01 \%$ ) for $5 \mathrm{~min}$, filtered onto $0.22 \mu \mathrm{m}$ black Nuclepore polycarbonate filter. Bacterial cells were counted in at least 25 randomly selected fields using $100 \times$ objective, and an epifluorescence microscope (Nikon). Average cell number per field was calculated, and used to estimate total bacterial cells following the procedure described by Parsons et al. (1984).

\subsubsection{Carbon and Nitrogen Analysis}

POC was analyzed spectrophotometrically by the wet oxidation of carbon with acid dichromate (Parsons et al., 1984). PON was estimated following the method of Raimbault and Slawyk. (1991). Coefficient of variation of analytical methods used for POC and PON based on five replicates was $2.5 \%$ and $4.2 \%$, respectively. Stable isotope $\left(\delta^{13} \mathrm{C}_{\mathrm{POC}}\right)$ was analyzed using the Thermo Finnigan Flash 1112 elemental analyzer, linked with a Thermo Finnigan Delta V plus Isotope Ratio MS using the following equation

$$
\delta^{13} \mathrm{C}_{\mathrm{POC}}=\left\{\left({ }^{13} \mathrm{C} /{ }^{12} \mathrm{C}\right)_{\text {Sample }} /\left({ }^{13} \mathrm{C} /{ }^{12} \mathrm{C}\right) \text { PDB }-1\right\} \times 1000
$$


The analytical precision for replicate samples was within $\pm 0.2 \%$ for $\delta^{13} \mathrm{C}_{\text {POC. }}$. All isotopic compositions are reported as, per-mil (\%o) relative to variation $(\partial)$ from the PDB standard.

\subsubsection{Analysis of total hydrolysable L-amino acids (THAA) and D- amino acids}

$\mathrm{GF} / \mathrm{F}$ filter containing the SPM were hydrolyzed with $6 \mathrm{~N} \mathrm{HCl}$ at $110{ }^{\circ} \mathrm{C}$ for $24 \mathrm{~h}$ and individual amino acids were separated and quantified following details described earlier (Bhosle et al., 2005). Briefly, to $50 \mu \mathrm{l}$ of the sample $50 \mu \mathrm{l}$ of the $o$-phthaldialdehyde (OPA) reagent was added (Lindroth and Mopper, 1979; Bhosle et al., 2005). The reaction was carried out for $2 \mathrm{~min}$, and $50 \mu \mathrm{l}$ sample was injected on the Varian Chrompack reversed phase column (4.6 mm ID, $15 \mathrm{~cm}$ length, $5 \mathrm{~mm}$ particle size). A binary solvent system consisting of $50 \mathrm{mM}$ sodium acetate buffer ( $\mathrm{pH}$ 6.5) containing $3 \%$ of tetrahydrofuran as solvent $\mathrm{A}$ and methanol as solvent $\mathrm{B}$ was used to separate amino acids which were subsequently detected using a fluorescence detector (excitation $\lambda=328$ and emission $\lambda=450 \mathrm{~nm})$. The relative standard deviation (SD) was between 0.4 to $14 \%(\mathrm{n}=5)$ for individual THAA.

For the D-amino acid analysis, method described by Fitznar et al. (1999) was used. D- and Lenantiomers of aspartic acid, glutamic acid, serine and alanine were separated and determined in the sample by high performance liquid chromatography (HPLC, Shimadzu model 1) using fluorescence detector (Ex: $330 \mathrm{~nm}$, Em: $445 \mathrm{~nm}$ ) after pre-column derivatisation with $o$-phthaldialdehyde and $N$ isobutyryl- L- cysteine. A Varian Chrompack reversed phase column (4.6 mm ID, $15 \mathrm{~cm}$ length, 5 mm particle size) was used to separated D-amino acids. A multi-step gradient system consisting of solvent $\mathrm{A}$ and $\mathrm{B}$ of $25 \mathrm{mM}$ sodium acetate buffer at $\mathrm{pH} 7.0$ and $\mathrm{pH} 5.3$, respectively, and methanol as solvent $\mathrm{C}$ at flow rate $1 \mathrm{ml} / \mathrm{min}$ was used for the amino acid separation. The calibration and quantification were done using external standards. The relative standard deviation (SD) was between 6 to $10 \%(\mathrm{n}=5)$ for $\mathrm{D}$ - amino acids. The stereoisomers of respective D-amino acids were corrected for racemization according to Kaiser and Benner. (2005).

\subsubsection{Bacterial contribution to POM}

The average $\mathrm{C}$ - and $\mathrm{N}$ - normalized yields of D-amino acids, observed during the monsoon and pre-monsoon seasons in the estuary were compared with yields calculated in different assemblage of bacteria (Bourgoin and Tremblay, 2010). The proportion of bacterial- $\mathrm{C}$ and $\mathrm{N}$ was calculated using the equation

$$
\% \text { Bacterial } \mathrm{C} \text { or } \mathrm{N}=100[\text { biomarker }]_{\text {sample }} /[\text { biomarker }]_{\text {bacteria }}
$$


Where [biomarker $]_{\text {Sample }}$ and [biomarker $]_{\text {bacteria }}$ are the $\mathrm{C}$ - or $\mathrm{N}$ - normalized yields of a specific biomarkers (e.g. D-alanine, D-aspartic acid and D-glutamic acid) in the SPM (sample) of Mandovi estuary and different assemblage of bacterial cells (bacteria).

\subsubsection{Statistical methods}

A simple regression analysis was performed to assess the relationships between parameters using excel program. One-way analysis of variance (ANOVA) was used to evaluate the significance of seasonal differences in amino acids. The degradation Index (DI) of OM was estimated using mol \% THAA composition and calculated using the formula proposed by Dauwe et al. (1999)

\section{Results}

\subsection{Hydrographic and bulk parameters}

The surface salinity decreased from station 01 to 09 during both the seasons, and was several folds higher during the pre-monsoon season. Average surface water temperature in monsoon was lower $\left(\sim 28 \pm 0.3^{\circ} \mathrm{C}\right)$ than the pre-monsoon $\left(\sim 31 \pm 0.4^{\circ} \mathrm{C}\right)$ (Table 1). Higher concentration of SPM, Chl $a$, POC, and PON were observed at downstream stations (stn 01, 02 and 03) and that decreased towards upstream station 08 (Table 1). These trends recorded for Chl $a$, POC, and PON were inversed in the pre-monsoon. Molar $\mathrm{C} / \mathrm{N}$ ratio varied from 5.8 to 22 and $\delta^{13} \mathrm{C}_{\mathrm{POC}}$ from -32 to $-25 \%$ during the monsoon. For the pre-monsoon, $\mathrm{C} / \mathrm{N}$ and $\delta^{13} \mathrm{C}_{\mathrm{POC}}$ ranged from 4.1 to 6.1 and -29.6 to $-21 \%$, respectively (Table 1$)$. In surface waters, TBC varied from $\left(5.4 \times 10^{8}\right)$ to $\left(42.1 \times 10^{8}\right)$ cells $/ 1$ (Table 1). TBC was lower during the monsoon than the pre-monsoon season (Table 1).

\subsection{Distribution and composition of total hydrolysable amino acids (THAA)}

THAA concentration decreased from downstream station 01 to upstream station 08 during the monsoon, and increased from the downstream station $01(1.4 \mu \mathrm{M})$ to upstream station $09(3.2 \mu \mathrm{M})$ (Fig. 2a) during the pre-monsoon season. During the monsoon, THAA yields (measured as \%THAAC/POC and \%THAA-N/PON), decreased from station 01 to 08 , except for station 07 , where THAA yields were slightly greater than those recorded at station 01 (Fig. 2 b, c). In the pre-monsoon, THAA yields increased from station 01 to 09 (Fig. 2b, c). The molecular composition of THAA did not show strong spatial differences during both the seasons and hence the mol \% data were averaged (Fig. 3a). In the monsoon, the most abundant amino acids were alanine, aspartic acid, leucine, serine, arginine, and threonine. In contrast, glutamic acid, glycine, valine, lysine, and isoleucine were the dominant amino acids during the pre-monsoon season (Fig. 3a). The non- protein amino acid, $\beta$ alanine was the minor component and accounted for $0.4 \pm 0.2 \%$ and $0.1 \pm 0.04 \%$ of THAA during monsoon and pre-monsoon season, respectively (Fig. 3a). DI values ranged between -1.8 and -0.4 
during the monsoon season. Except for station 02, the DI values became more negative towards the upstream end stations 07 and 08 (Fig. 3b). In the pre-monsoon, DI values were positive and varied between +0.5 and +1.3 (Fig. $3 b$ ).

\subsection{Distribution of D-amino acids}

D-isomers of alanine, glutamic acid, aspartic acid, and serine were detected in the Mandovi estuary. D-amino acid concentrations were low ( 9.0 to $25.3 \mathrm{nM})$ during the monsoon as compared to the pre-monsoon season (22.1 to $36.7 \mathrm{nM}$ ) (Table 2). Total D-amino acids accounted for 1.1 to 11.5 mol \% and 1.5 to $2.8 \mathrm{~mol} \%$ of THAA during monsoon and pre-monsoon season, respectively (Table 2). Spatially, mol \% D-amino acid increased towards the upstream end, with highest contribution at station 06 (11.5 mol \%) (Table 2).

Based on biomarker yields, bacteria accounted for 16 to $34 \%(23.0 \pm 6.7 \%)$ of POC and 29 to 75 $\%(47.9 \pm 18.7 \%)$ of PON during monsoon, and 30 to $78 \%(50.0 \pm 15 \%)$ of POC and 34 to $79 \%$ $(51.2 \pm 13.3 \%)$ of PON during the pre-monsoon season (Table 2$)$.

\section{Discussion}

\subsection{Bulk Parameters}

Mandovi estuary experiences distinct environmental conditions during the monsoon and premonsoon season. The estuary receive heavy river run-off during southwest monsoon. However, during the pre-monsoon season there is negligible water discharge and the estuary experiences marine condition due to intrusion of seawater several kilometers upstream from the mouth of the estuary. SPM trend observed in the Mandovi estuary was different from those observed for other estuaries wherein, SPM decreased from freshwater end to seawater end (Grabemann et al., 1997, Chen et al., 2004). During monsoon, the higher SPM concentration at the stations near the estuary mouth was the result of re-suspension of bottom sediments due to presence of strong tidal currents, westerly winds and waves (Qasim and Sen Gupta, 1981).

\section{Table 1}

$\delta^{13} \mathrm{C}_{\mathrm{POC}}$ signatures of the various carbon sources are often different and therefore useful tracer to carbon inputs in various environments. In the aquatic ecosystems, the $\delta^{13} \mathrm{C}_{\mathrm{POC}}$ varied broadly for terrestrial C3 plants (-30 \%o to - $26 \%$ ), marine phytoplankton (-22 \%o to - $18 \%$ ), and mangrove leaves (-35 \%o to -22 \%o ) (Cifuentes, 1991; Dittmar et al., 2001a; Wu et al., 2007a; Bouillon et al., 2008). $\delta^{13} \mathrm{C}_{\mathrm{POC}}$ values of POM in the present study area were depleted ( $-32 \%$ to $-25 \%$ ) during the monsoon than those recorded for the pre-monsoon season (-29.6\%o to $-21 \%$ o) (Table 1). The $\delta^{13} \mathrm{C}_{\mathrm{POC}}$ 
values of SPM of Mandovi estuary are similar to those recorded for terrestrial C3 plants and mangrove leaves in the monsoon season and phytoplankton $\delta^{13} \mathrm{C}_{\mathrm{POC}}$ during the pre-monsoon season (Smith and Epstein, 1971; Dittmar et al., 2001a; Wu et al., 2007a; Bouillon et al., 2008).

In estuaries and rivers, $\mathrm{OM}$ is derived from various sources including autochthonous and allochthonous sources. The average $\mathrm{C} / \mathrm{N}$ ratio for the fresh living phytoplankton and bacteria is 7 and 4, respectively (Redfield et al., 1963; Lee and Furhman, 1987), while for the terrestrial OM, it varied from 12 to 200 (Hedges and Man, 1979) which decreases during degradation due to incorporation of exogenous nitrogen known as N-enrichment (Temblay and Benner, 2006). The higher and lower $\mathrm{C} / \mathrm{N}$ ratio during the monsoon and pre-monsoon season, respectively, suggests the presence of degraded terrestrial and relatively fresh OM of phytoplankton origin during the former and latter season, respectively. However, $\mathrm{C} / \mathrm{N}$ ratios during the monsoon were much lower than those recorded for terrestrial OM, thereby suggesting N-enrichment due to bacterial contribution to the organic nitrogen (Tremblay and Benner, 2006).

\subsection{Amino acids concentrations}

THAA values observed in the Mandovi estuary are in the range of values observed for other rivers, estuaries, and coastal region (Ittekkot and Zhang, 1989; Hedges et al., 1994; Chen et al., 2004; Duan and Bianchi, 2007; Wu et al., 2007b). During monsoon, higher THAA concentrations at the downstream stations (stn 01 to 03) maybe due to hydrodynamic sorting of SPM (Duan and Bianchi, 2007). During low discharge period there is rapid settling of large suspended particles, which are temporarily stored in the riverbed. Moreover, in the Mandovi estuary during the non-monsoon season, a sand bar develops at the mouth of the estuary, wherein suspended particles are trapped and stored (Qazim and Sen Gupta, 1981). In the monsoon due to the combined effect of higher river runoff and physical forcing, amino acid rich bottom sediments are re-suspended. Therefore, higher THAA concentration at the stations 01 to 03 (Fig. 2a) was probably due to re-suspension of the trapped POM (Duan and Bianchi, 2007; Wu et al 2007b). The intense river flow during the monsoon is counteracted by the strong tidal and wind induced currents (Rao et al., 2011), which may have led to the lateral advection or transport of THAA from station 01 to 03 . The low THAA observed at station 04 to 08 during the monsoon was due to the presence of degraded terrestrial OM or poor growth of phytoplankton at these stations due to greater turbidity and poor light conditions. This was also supported by a poor relationship $(\mathrm{r}=0.264, \mathrm{n}=8)$ between Chl $a$ and THAA suggesting the phytoplankton biomass did not Influence THAA concentration 
Fig. 2

during the monsoon. In contrast, during the pre-monsoon, although the SPM levels were high, improved light conditions favored the growth of in situ phytoplankton resulting into higher THAA concentrations (Fig. 2a). This was also supported by a positive relationship between THAA and Chl $a(\mathrm{r}=0.6804, \mathrm{n}=9, \mathrm{p}<0.02)$. Abundance of amino acid in the Mandovi estuary was significantly affected by the change in the season $(\mathrm{F}=24, \mathrm{p}<0.0001)$.

THAAs account for a major fraction of the freshly produced OM, and are relatively labile compared to bulk OM (Ittekkot and Arain, 1986; Cowie and Hedges, 1994). THAA yields (measured as \%THAA-C/POC and \%THAA-N/PON) decrease during OM degradation and therefore, used to assess the degradation state of OM (Cowie and Hedges, 1992; Davis et al., 2009). During the monsoon season, THAA yields were lower than that of freshly derived phytoplankton OM. Moreover, the THAA yields decreased from station 01 to 08 . Low THAA yields indicate that the OM was substantially degraded during the monsoon (Fig. 2b, c). Another reason for the low THAA yield was the presence of terrestrial OM, which contains lesser amino acids than phytoplankton (Cowie and Hedges, 1992; Hedges et al., 1997). Ittekkot and Arain (1986) suggest a concept wherein the microbially re-worked OM from the flood plains is transported into the main channels during the high sediment discharge period. The processes occurring in the flood plains and the introduction of the re-worked OM control the composition of the POC carried by these rivers. They observed that POC associated with high sediment discharge period contains much less labile constituents such as amino acids. This concept may also hold true for the Mandovi estuary during the monsoon season where low contribution of THAA to POC was observed during the high sediment discharge period. Conversely, during the pre-monsoon season, the THAA yields were greater and generally increased from station 01 to station 09. This suggests that POM was relatively fresh and of phytoplankton origin during pre-monsoon season.

\subsection{Molecular composition of amino acids}

Amino acid composition in source organisms is relatively constant. However, a change in the amino acid composition of suspended particles is mainly due to the alterations as a result of biodegradation and different reactivities of individual amino acid. Thus, amino acids are useful indicators to identify OM degradation state (Cowie and Hedges, 1994; Dauwe and Middelburg, 1998; Dauwe et al., 1999; Keil et al., 2000; Chen et al., 2004). In the Mandovi estuary, the molecular composition of THAA did not, show strong spatial differences during both the seasons and hence mol \% data was averaged (Fig. 3a). In general, the THAA composition of the Mandovi estuary 
agrees well with THAA composition of SPM from other world rivers (Hedges et al., 1994; Chen et al., 2004; Duan and Bianchi, 2007; Wu et al., 2007b; Bourgoin and Tremblay, 2010), estuaries and coastal environment (Cowie and Hedges, 1992; Dauwe and Middelburg, 1998).

Fig. 3

The changes in the amino acid composition during OM decomposition depend primarily on the amino acids and their association with cell wall, cell membrane or cell plasma, and/or sorption onto mineral surfaces (Aufdenkampe et al., 2001). The observed higher amount of non-protein amino acid, $\beta$-alanine, and cell wall amino acids serine, threonine and alanine indicates that the OM was relatively degraded during the monsoon season (Fig. 3a). In contrast, enrichment of the glutamic acid, valine, isoleucine, and lysine, along with depletion in mol \% serine, threonine, alanine, and $\beta$ alanine indicates the presence of relatively fresher OM during the pre-monsoon season (Fig. 3a).

Glycine and the hydroxyl amino acids, serine and threonine are enriched in diatom cell walls (Hecky et al., 1973). The association of these amino acids with the cell wall protects them from degradation, resulting in their accumulation in degraded OM (Dauwe and Middelburg, 1998). However, the presence of glycine and serine, in the structural matrices of diatoms and bacteria, cannot be the only possible reason for their enrichment in OM. Ogren and Chollet. (1982) observed the release of glycine and serine by growing algal cells during photorespiration. Enrichment of glycine also may be because it is a short chain amino acid, has minor food value, and is synthesized from other amino acids during heterotrophic metabolism. Dauwe et al. (1999) observed higher proportion of glycine and alanine in the highly degraded OM. Therefore, the higher abundance of alanine along with glycine during the monsoon indicates presence of highly degraded OM. The observed higher mol \% of aspartic acid, serine, arginine, alanine and leucine and low mol \% of glycine during the monsoon than the pre-monsoon season, maybe due to the presence of terrestrial $\mathrm{OM}$ during the former season. These amino acids are found to be more abundant in vascular plant tissues as compared to phytoplankton (Cowie and Hedges, 1992). Wu et al. (2007b) observed abundance of alanine, threonine, arginine, and leucine in the terrestrial OM of Yangtze riverine OM. Amino acids such glutamic acid, aspartic acid, isoleucine, valine, tyrosine, and phenylalanine are generally concentrated in diatom cell plasma (Hecky et al., 1973; Dauwe and Middelburg, 1998) and are found to be easily susceptible to degradation and are abundant in freshly derived marine OM. These amino acids show strong depletion with increasing state of decomposition. The non-protein amino acids, $\beta$-alanine, is the bacterial degradation byproduct of protein amino acid aspartic acid. 
This non- protein amino acid is generally absent or present at trace level in living organisms, however mol \% of $\beta$-alanine increases with OM degradation (Cowie and Hedges, 1992).

Amino acid degradation index (DI) is another proxy for assessing the degradation state of OM. In the Mandovi estuary, the low and negative values of DI's during monsoon season indicate that the $\mathrm{OM}$ at most of the stations in the estuary was relatively degraded (Fig. 3b). This conclusion was also supported by high $\mathrm{C} / \mathrm{N}$ ratio, and mol \% D-amino acids, and low THAA yields. Conversely, greater and positive DI (Fig. 3b), higher \% THAA yields, and lower $\mathrm{C} / \mathrm{N}$ ratio and mole \% D-amino acids all indicate the presence of relatively fresh OM during the pre-monsoon season.

\subsection{D-Amino acid concentration and Composition}

Heterotrophic bacteria are the primary agent of decomposition of terrestrial and planktonic OM in aquatic environments. D-amino acids are derived from bacterial cell wall, and bacterial macromolecules but are absent in phytoplankton or vascular plants (Kaiser and Benner, 2008). In the Mandovi estuary, a shift in the ecosystem production from net heterotrophy to net autotrophy occurs during the pre-moonsoon season (Khodse et al., 2010). The higher D-amino acid concentration observed during the pre-monsoon season (Table 2) indicate that accumulation of bacterial remnants due to diagenetic processes was not the reason for the observed higher D-amino acids concentrations in the Mandovi estuary. Since other diagenetic indicators such as DI, non-protein amino acid, and THAA yields, indicates an increased bacterial biomass (McCarthy et al., 2004). This was also supported by a significant positive relationship between the total bacterial count (Table 1) and Damino acids concentrations $(\mathrm{r}=0.6993, \mathrm{n}=9, \mathrm{p}<0.02)$.

Table 2

D-amino acids (as mol \%) are useful biomarkers to assess OM degradation (Jorgensen et al., 2003; Nagata et al., 2003; Wu et al., 2007b; Tremblay and Benner, 2009). In the Mandovi estuary, D-amino acids accounted for 1.1 to $11.5 \mathrm{~mol} \%$ of total THAA, indicating greater bacterial contribution to the OM during the monsoon season. Further the mol \% D-amino acids increased towards the upstream end, and highest contribution of D-amino acid to THAA was observed at station 06 (11.5 mol \%) (Table 2). Mol \% D-amino acids observed during pre-monsoon were relatively low (1.5 to $2.8 \mathrm{~mol} \%$ ). D-amino acids were highest at station 06 suggesting the presence of degraded OM. This conclusion is well supported by low THAA yield and high C/N ratio of POM at this station. A significant inverse $(r=-0.7364, n=15, p<0.001)$ relationship was observed for mole $\% \mathrm{D}$-amino acid and DI, suggesting that D-amino acids indicate degradation of OM. 


\subsection{Bacterial contributions to the POM}

In an estuary, activities of heterotrophic bacteria play an important role in determining the quality and quantity of OM. In view of this, assessing bacterial contribution to OM in estuaries is extremely important and challenging. D- amino acids are useful proxies to assess bacterial contribution. This is because D-amino acids are produced by bacteria and not by phytoplankton. It is assumed that Damino acid yields in cultured bacteria are representative of natural assemblages, and their reactivities are representative of bulk carbon and nitrogen reactivites (Kaiser and Benner, 2008; Tremblay and Benner, 2009; Bourgoin and Tremblay, 2010). In this study, we used D-amino acids yields to calculate bacterial contribution to OM using average bacterial yields taken from published literature on bacterial assemblages typically found in soils and freshwaters and estuarine system (Bourgoin and Tremblay, 2010). We used yields of D-alanine and D-glutamic acid to calculate the bacterial contribution to bulk $\mathrm{OM}$ as D-aspartic acid and D-serine yields were highly variable and greater than those recorded for bacteria (Kaiser and Benner, 2008). Estimates of bacterial-C to POC varied from 16 to $34 \%$ for monsoon and 30 to $78 \%$ for pre-monsoon season (Table 2). Similarly, estimates of bacterial-N contribution to PON ranged between 29 to $75 \%$, and 34 to $79 \%$ for monsoon and premonsoon season, respectively (Table 2). The estimate of bacterial- $\mathrm{C}$ and $\mathrm{N}$ obtained for the Mandovi estuary is in the range of values reported by others Kaiser and Benner, 2008; Temblay and Benner, 2009; Bourgoin and Tremblay, 2010). Bacteria accounted for $\sim 25 \%$ of $\mathrm{C}$ and $\sim 50 \%$ of $\mathrm{N}$ in marine POM from the Sargasso Sea in North Atlantic Ocean and North Pacific Ocean (Kaiser and Benner, 2008). Tremblay and Benner. (2009) estimated 4 - $17 \%$ of the $\mathrm{C}$ and $17-37 \%$ of the $\mathrm{N}$ in the POM of Amazon River, whereas bacterial OM accounted for $\sim 20 \%$ of POC and $\sim 40-70 \%$ of PON in the St. Lawerence system (Bourgoin and Tremblay, 2010). Bacterial $-\mathrm{N}$ contribution to PON in monsoon appears to be similar to that observed for pre-monsoon (Table 2). $\delta^{13} \mathrm{C}_{\mathrm{POC}}$ suggests that the $\mathrm{OM}$ in monsoon was mostly derived from terrestrial sources. If the OM was of terrestrial origin, then we would expect higher $\mathrm{C} / \mathrm{N}$ ratio $(>20)$ since terrestrial $\mathrm{OM}$ is nitrogen poor. However, $\mathrm{C} / \mathrm{N}$ ratios of $\mathrm{OM}$ were lower $(<13)$ with the exception of one value than those recorded for terrestrial OM. In view of this, the lower $\mathrm{C} / \mathrm{N}$ ratio strongly suggests the enrichment of bacterial $-\mathrm{N}$ on the terrestrial OM. It is documented that biodegradation of terrestrial OM results in bacterial enrichment (Tremblay and Benner, 2006). Such enrichment of bacterial $-\mathrm{N}$ on terrestrial OM may have reduced the differences in bacterial $-\mathrm{N}$ contribution in monsoon and pre-monsoon season.

\section{Conclusion:}

In the Mandovi estuary, POM was mostly derived from terrestrial sources during the monsoon and from phytoplankton during the pre-monsoon season. The distribution of the amino acids in the 
estuary is governed to a greater extent by the biological processes. Bacteria played an important role in deciding the quality and quantity of $\mathrm{OM}$ in the estuary. Amino acid composition and $\mathrm{OM}$ degradation indicators including THAA yields, mol \% D-AA, and DI suggest that the OM was substantially degraded during the monsoon season, and was relatively fresher during the premonsoon season. Higher concentrations of D-amino acids during the pre-monsoon season indicate higher bacterial biomass and not the degradation of $\mathrm{OM}$ was responsible for the observed abundance of D-amino acids. Moreover, bacteria appear to contribute substantially to POM during both the monsoon and pre-monsoon in the Mandovi estuary.

\section{Acknowledgments}

The author is grateful to Dr. Satish R. Shetye, the director, National Institute of Oceanography, Goa for his support and encouragement. I am also gratified to Dr. N. B. Bhosle for suggesting the topic, and for teaching to analyze L-and D-amino acids. I appreciate the help rendered by Mr. A. P. Selvam for the operation of the HPLC and Ms. Anita Garg in the preparation of the Manuscript. I would also like to acknowledge BOBPS project from where I began my research tenure and CSIR, New Delhi for providing the research Fellowship. I also thank my Colleagues Mr. Manoj N T and Mr. Vishwas Khodse for their sampling assistance.

\section{References}

Aufdenkampe, A.K., Hedges, J.I., Richey, J. E., Krusche, A.V., Lerena, C.A., 2001. Sorptive fractionation of dissolved organic nitrogen and amino acids onto fine sediments within the Amazon Basin. Limnology Oceanography 46, 1921-1935.

Bhosle, N.B., Garg, A., Fernandes, L., Citon, P., 2005. Dynamics of amino acids in the conditioning film developed on glass panels immersed in the surface seawaters of Dona Paula Bay. Biofouling 21, 99-107.

Boto, K.G., Bunt, J.S., 1978. Selective excitation fluorometry for the determination of Chlorophylls and Pheophytins. Analytical Chemistry 50, 392-395.

Bouillon, S., Connolly, R.M., Lee, S.Y., 2008. Organic matter exchange and cycling in mangrove ecosystems: Recent insights from stable isotope studies. Journal of Sea Research 59, 44-58.

Bourgoin, L,-H., Tremblay, L., 2010. Bacterial reworking of terrigenous and marine organic matter in estuarine water columns and sediments. Geochimica Et Cosmochimica Acta 74, 5593-5609.

Canuel, E.A., Cloern, J.E., Ringelberg, D.B., Guckert, J.B., Rau, G.H., 1995. Molecular and isotopic tracers used to examine sources of organic matter and its incorporation into the food webs of San Francisco Bay. Limnology Oceanography 40, 67-81. 
Chen, J., Li, Y., Yin, K., Jin, H., 2004. Amino acids in the Pearl River Estuary and adjacent waters: origins, transformation and degradation. Continental Shelf Research 24, 1877-1894.

Cifuentes, L.A., 1991. Spatial and temporal variations in terrestrially derived organic matter from sediments of the Delaware estuary. Estuaries 14, 235-246.

Cloern, J.E., Canuel, E.A., Harries, D., 2002. Stable carbon and nitrogen isotope composition of aquatic and terrestrial plants of the San Francisco Bay estuarine system. Limnology Oceanography 47, 713-729.

Cowie, G.L., Hedges, J.I., 1992. Sources and reactivities of amino acids in a coastal marine environment. Limnology and Oceanography 37, 703-724.

Cowie, G.L., Hedges, J.I., 1994. Biochemical indicators of diagenic alteration in natural organic matter mixtures. Nature 369, 304-307.

Dauwe, B., Middelburg, J.J., Herman, P.M.J., Heip, C.H.R., 1999. Linking diagenetic alteration of amino acids and bulk organic matter reactivity. Limnology Oceanography 44, $1809-1814$.

Dauwe, B., Middelburg, J.J., 1998. Amino acids and hexosamines as indicators of organic matter degradation state in North Sea sediments. Limnology and Oceanography 43, 782-798.

Davis, J., Kaiser, K., Benner, R., 2009. Amino acid and amino sugar yields and compositions as indicators of organic matter diagenesis. Organic Geochemistry 40, 343-352.

Dittmar, T., Lara, R.J., Kattner, G., 2001a. River or mangrove? Tracing major organic sources in tropical Brazilian coastal waters. Marine Chemistry 73, 253-271.

Dittmar, T., Fitznar, H.P., Kattner, G., 2001b. Origin and biogeochemical cycling of organic nitrogen in the eastern Arctic Ocean as evident from D- and L-amino acids. Geochimica Et Cosmochimica Acta 65, 4103-4114.

Duan, S., Bianchi, T.S., 2007. Particulate and dissolved amino acids in the lower Mississippi and Pearl Rivers (USA). Marine Chemistry 107, 214-229

Findlay, S., Pace, M.L., Lints, D., Howe, K., 1992. Bacterial metabolism of organic carbon in tidal freshwater Hudson estuary. Marine Ecology Progress Series 89, 147-153.

Fitznar, H.P., Lobbes, J.M., Kattner, G., 1999. Determination of enantiomeric amino acids with highperformance liquid chromatography and pre-column derivatisation with o-phthaldialdehyde and $\mathrm{N}$-isobutyrylcysteine in seawater and fossil samples (mollusks). Journal of Chromatography A $832,123-132$.

Grabemann, I., Uncles, R.J., Krause, G., Stephens, J.A., 1997. Behaviour of turbidity maxima in the Tamar (U.K.) and Weser (F.R.G.) estuaries. Estuarine. Coastal and Shelf Science 45, 235- 246. 
Grutters, M., van Raaphorst,W., Epping, E., Helder, W., de Leeuw, J.W., 2002. Preservation of amino acids from in situ-produced bacterial cell wall peptidoglycans in northeastern Atlantic continental margin sediments. Limnology Oceanography 47, 1521-1524.

Gupta, L. P., Kawahata, H., 2000. Amino acid and hexosamine compositions and flux of sinking particulate matter into the equatorial Pacific at $175^{\circ}$ E longitude. Deep-Sea Research 47, $1937-$ 1960.

Harvey, H.R., Macko, S.A., 1997. Catalysts or contributors? Tracking bacterial mediation of early diagenesis in the marine water column. Organic Geochemistry 26, 531-544.

Hecky, R.E., Mopper, K., Kilham, P., Degens, E.T., 1973. The amino acid and sugar composition of diatom cell-walls. Marine Biology 19, 51-60.

Hedges, J. I., Man, D.C., 1979. The characterization of plant tissues by their lignin oxidation products. Geochemica Et Cosmochimica Acta 43, 1803-1807.

Hedges, J.I., Prahl, F.G., 1993. Early diagenesis: Consequences for applications of molecular biomarkers. In M. H. Engel and S. A. Macko [eds.], Organic geochemistry: Principles and applications, Plenum, pp. 237-253.

Hedges, J.I., Cowie, G.L., Richey, J.E., Quay, P.D., Benner, R., Strom, M., Forsberg, B.R., 1994. Origins and processing of organic matter in the Amazon River as indicated by carbohydrates and amino acids. Limnology and Oceanography 39, 743-761.

Hedges, J.I., Keil, R.G., Benner, R., 1997. What happens to terrestrial organic matter in the ocean? Organic Geochemistry 27, 195-212.

Ittekkot, V., Arain, R., 1986. Nature of particulate organic matter in the river Indus, Pakistan. Geochimica Et Cosmochimica Acta 50, 1643- 1653.

Ittekkot, V., Zhang, S., 1989. Pattern of particulate nitrogen transport in world rivers. Global Biogeochemical Cycles 3, 383-391.

Jorgensen, N.O.G., Tranvik, L.J., Berg, G.M., 1999. Occurrence and bacterial cycling of dissolved nitrogen in the Gulf of Riga, the Baltic Sea. Marine Ecology Progress Series 191, 1-18.

Jorgensen, N.O.G., Stepanaukas, R., Pedersen, A.G.U., Hansen, M., Nybroe, O., 2003. Occurrence and degradation of peptidoglycan in aquatic environments. FEMS Microbiology Ecology 46, 269-280.

Kaiser, K., Benner, R., 2005. Hydrolysis-induced racemization of amino acids. Limnology Oceanography Methods 3, 318-325.

Kaiser, K., Benner, R., 2008. Major bacterial contribution to the ocean reservoir of detrital organic carbon and nitrogen. Limnology Oceanography 53, 99-112. 
Keil, R.G., Tsamakis, E., Hedges, J.I., 2000. Early diagenesis or particulate amino acids in marine sediments. In: Goodfriend GA, Collins MJ, Fogel ML, Macko SA, Wehmiller JF (Eds) Perspectives in amino acid and protein chemistry. Oxford University Press, New York, p 69-82.

Khodse, V.B., Bhosle, N.B., Matondkar, S.G.P., 2010. Distribution of dissolved carbohydrates and uronic acids in a tropical estuary, India. Journal of Earth System Science 119, 519-530.

Lee, S., Fuhrman, J.A., 1987. Relationships between biovolume and biomass of naturally derived marine bacterioplankton. Applied and Environmental Microbiology 53, 1298-1303.

Lee, C., Wakeham, S., Arnosti, C., 2004. Particulate organic matter in the sea: The composition conundrum. Ambio 33, 565-575.

Lindroth, P., Mopper, K., 1979. High performance liquid chromatographic determination of subpicomole amounts of amino acids by precolumn fluorescence derivatization with $O$ phthaldialdehyde. Analytical Chemistry 51, $1667-1674$.

Lomstein, B. A., Niggemann J., Jorgensen, B. B., Langerhuus, A.T., 2009. Accumulation of prokaryotic remains during organic matter diagenesis in surface sediments off Peru. Limnology Oceanography 54, $1139-1151$.

McCarthy, M. D., Benner, R., Lee, C., Hedges, J. I., Fogel, M. L., 2004. Amino acid carbon isotopic fractionation patterns in oceanic dissolved organic matter: An unaltered photoautotrophic source for dissolved organic nitrogen in the ocean? Marine Chemistry 92, 123-134.

Nagata, T., Meon, B., Kirchman, D.L., 2003. Microbial degradation of peptidoglycan in seawater. Limnology Oceanography 48, 745-754.

Ogawa, H., Amagai, Y., Koike, I., Kaiser, K., Benner, R., 2001. Production of refractory dissolved organic matter by bacteria. Science 292, $917-920$.

Ogren, W.L., Chollet, R., 1982. Photorespiration. In: Govindjee,A.(Ed.), Photo- synthesis: Development, Carbon Metabolism, and Plant Productivity. Academic, pp. 192-230.

Parsons, T.R., Maita, Y., Lalli, C.M., 1984. A manual of chemical and biological methods for seawater analysis. (Oxford: Pergamon).

Pedersen, A.-G.U., Thomsen, T.R., Lomstein, B.Aa., Jorgensen, N.O.G., 2001. Bacterial influence on amino acid enantiomerization in a coastal marine sediment. Limnology Oceanography 46, 1358-1369.

Qasim, S. Z., Sen Gupta, R., 1981. Environmental characteristics of the Mandovi-Zuari estuarine system in Goa. Estuarine Coastal Marine Science 13, 557-578.

Raimbault, P., Slawyk, G., 1991. A semiautomatic wet oxidation method for the determination of particulate organic nitrogen collected on filters. Limnology Oceanography 36, 405-408. 
Rao, V.P., Shynu, R., Kessarkar, P.M., Michael, G.S., Narvekar, T., Viegas, B., Mehra, P., 2011. Suspended sediment dynamics on a seasonal scale in the Mandovi and Zuari estuaries, central west coast of India. Estuarine, Coastal and Shelf Science 91, 78-86.

Redfield, A.C., Ketchum, B.H., Richards, F.A., 1963. The influence of organisms on the composition of sea-water. In: Hill, M.N. (Ed.), The Sea. Wiley, New York, pp. 26-77.

Schlesinger W.H., Melack J.M., 1981. Transport of organic carbon in the worlds rivers. Tellus 33, $172-187$.

Shetye, S.R., Kumar, M.D., Shankar, D., 2007. The Mandovi and Zuari estuaries. National Institute of Oceanography, Goa, 145 pp.

Smith, B.N., Epstein, S., 1971. Two categories of 13C/12C ratios for higher plants. Plant Physiology 47, 380-384.

Tremblay, L., Benner, R., 2006. Microbial contributions to $\mathrm{N}$-immobilization and organic matter preservation in decaying plant detritus. Geochimica Et Cosmochimica Acta 70, 133-146.

Tremblay, L., Benner, R., 2009. Organic matter diagenesis and bacterial contributions to detrital carbon and nitrogen in the Amazon River system. Limnology Oceanography 54, 681-691.

Vandewiele, S., Cowie, G., Soetaert, K., Middelburg, J. J., 2009. Amino acid biogeochemistry and organic matter degradation state across the Pakistan margin oxygen minimum zone. Deep Sea Research II 56, 318-334.

Wu, Y., Zhang, J., Liu, S.M., Zhang, Z.F., Yao, Q.Z., Hong, G.H., Cooper, L., 2007a. Sources and distribution of carbon within the Yangtze River system. Estuarine, Coastal and Shelf Science $71,13-25$.

Wu, Y., Dittmar, T., Ludwichowski, K-U., Kattner, G., Zhang, J., Zhu, Z.Y., Koch, B. P., 2007 b. Tracing suspended organic nitrogen from the Yangtze River catchment into the East China Sea. Marine chemistry 107, 367-377.

Zhang, J., Yu, Z.G., Liu, S.M., Xu, H., Wen, Q.B., Shao, B., Chen, J.F., 1997. Dominance of terrigenous particulate organic carbon in the high-turbidity Shuangtaizihe estuary. Chemical Geology 138, 211-219. 


\section{Figure Captions}

Fig. 1. Map showing sampling site and stations sampled in the Mandovi estuary, west coast of India.

Fig. 2. Distribution of THAA concentration (a), \% THAA-C (b), \% THAA-N (c), in the Mandovi estuary.

Fig. 3. Average mol percentages of total hydrolysable amino acids (THAA), bar indicates standard deviation (a) and DI (b) in the Mandovi estuary.

\section{Figures}

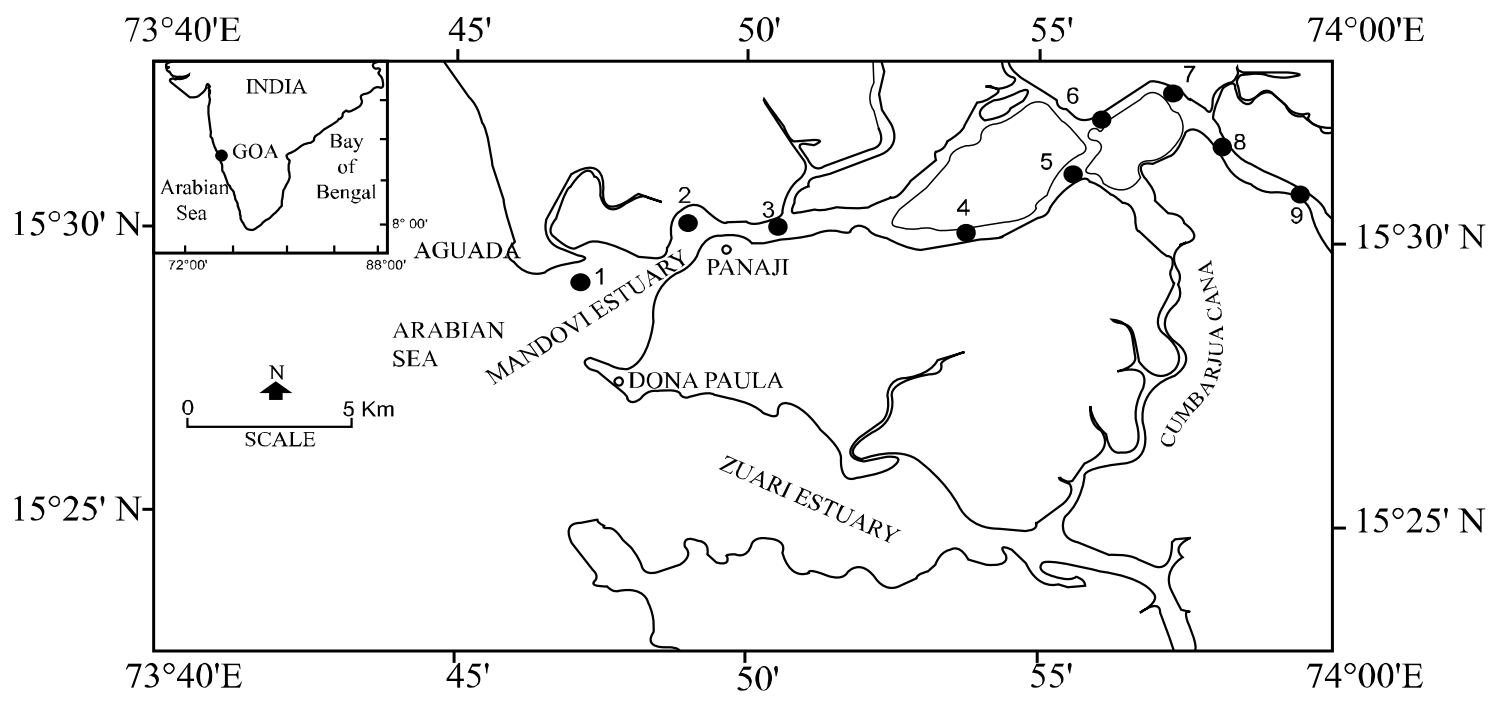

Fig. 1. 

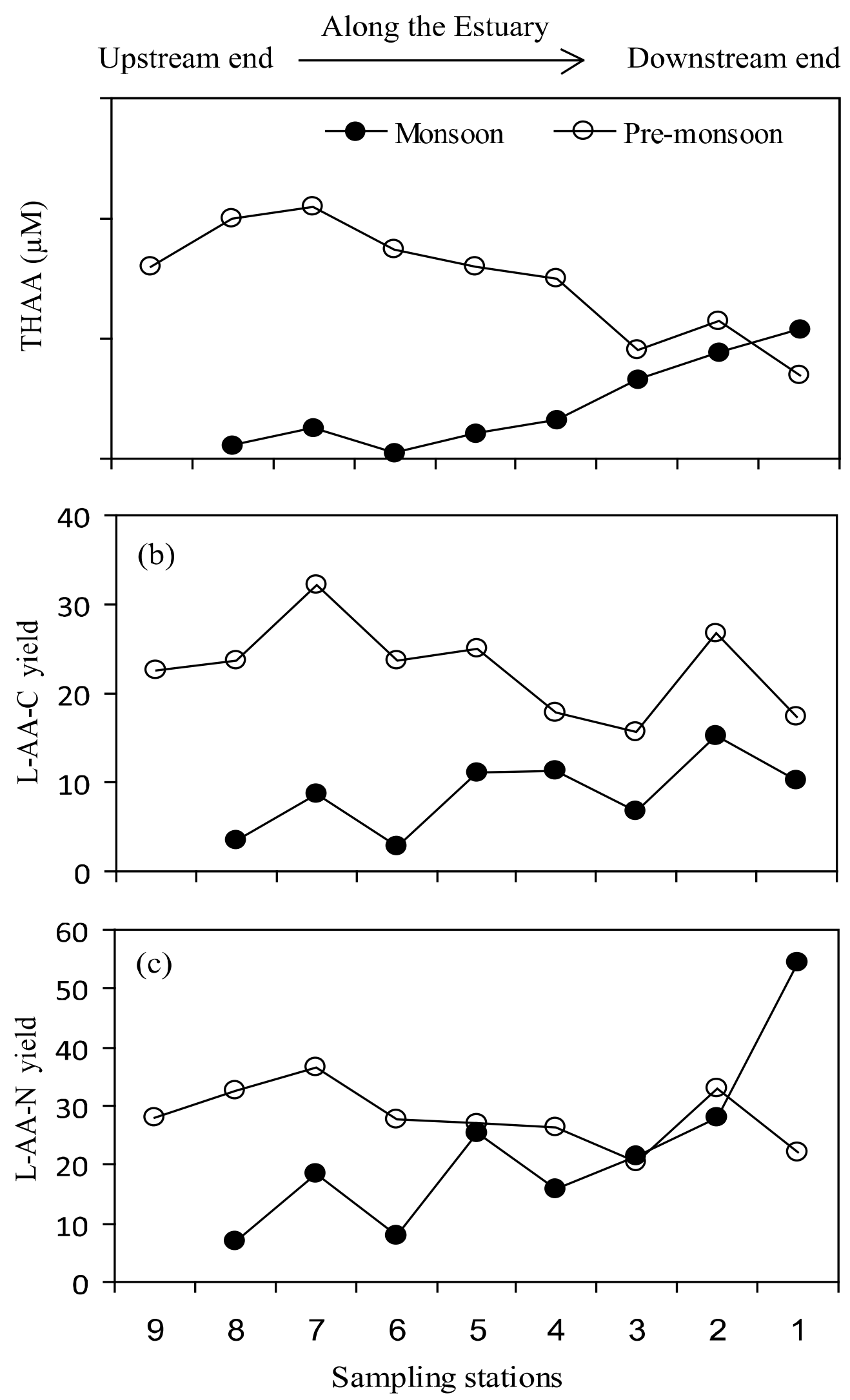

Fig. 2. 


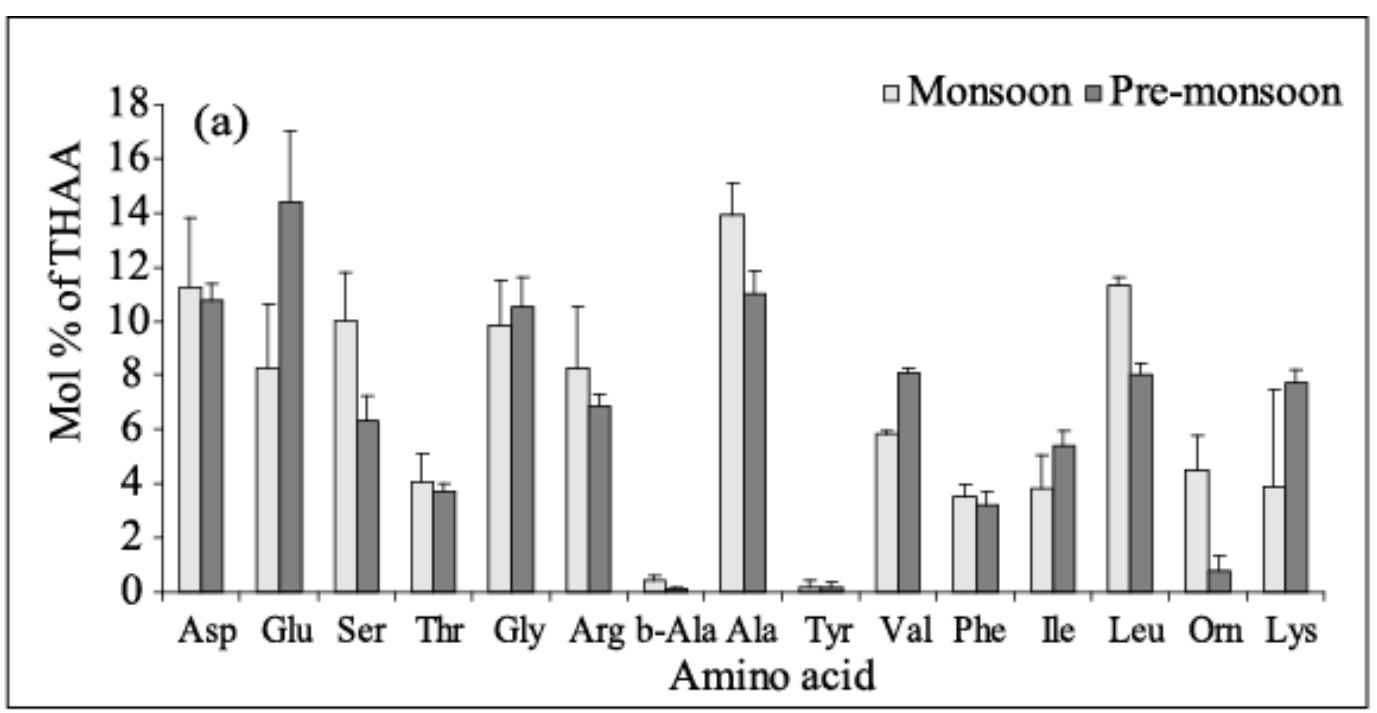

(b)

- Monsoon O Pre-monsoon

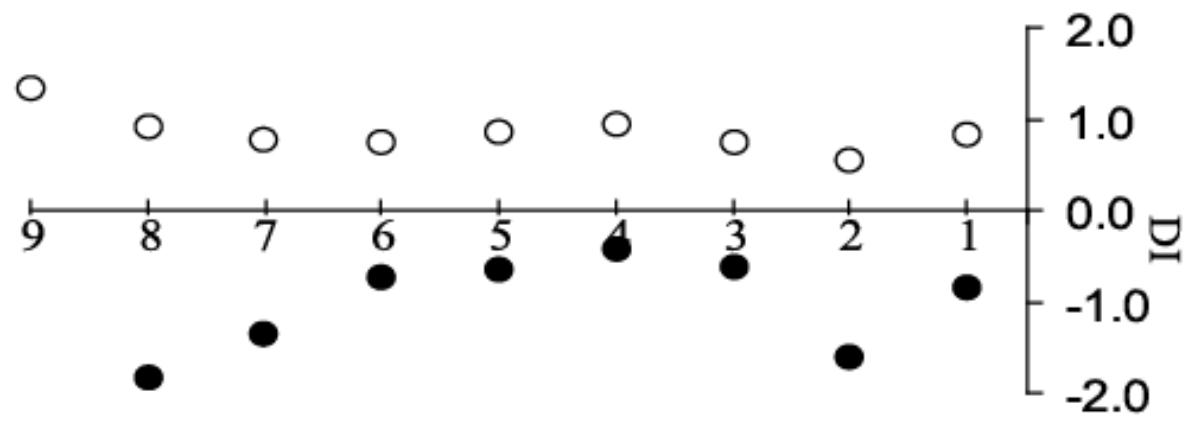

Sampling stations

Upstream end $\stackrel{\text { Along the Estuary }}{\longrightarrow}$ Downstream end

Fig. 3. 
Table 1

Distribution of hydrographic and bulk parameters at various sampling stations during the monsoon and pre-monsoon season in the Mandovi estuary

\begin{tabular}{cccccccccc}
\hline Stations & Temperature & Salinity & SPM & Chl $a$ & POC & TPN & C/N & $\delta^{13} C_{\text {POC }}$ & TBC \\
& $\left({ }^{\circ} \mathrm{C}\right)$ & & $(\mathrm{mg} / \mathrm{l})$ & $(\mu \mathrm{g} / \mathrm{l})$ & $(\mu \mathrm{M} \mathrm{C})$ & $(\mu \mathrm{M} \mathrm{N})$ & ratio & $\left(\mathrm{x} \mathrm{10}{ }^{8}\right.$ cells/l) \\
\hline
\end{tabular}

\section{Monsoon season}

\begin{tabular}{|c|c|c|c|c|c|c|c|c|c|}
\hline Stn1 & 27.4 & 16.34 & 16.9 & 4.5 & 107.8 & 4.9 & 22.0 & -25.1 & 29.1 \\
\hline $\operatorname{Stn} 2$ & 27.6 & 14.58 & 17.4 & 4.7 & 59.1 & 7.8 & 7.6 & -32.1 & 12.3 \\
\hline $\operatorname{Stn} 3$ & 27.6 & 13.40 & 18.4 & 4.3 & 98.2 & 7.6 & 12.9 & -26.1 & 28.1 \\
\hline $\operatorname{Stn} 4$ & 28.1 & 1.03 & 9.6 & 2.1 & 29.1 & 5.0 & 5.8 & -27.7 & 5.4 \\
\hline $\operatorname{Stn} 5$ & 27.5 & 0.14 & 4.0 & 1.3 & 19.8 & 2.1 & 9.4 & -28.7 & 9.3 \\
\hline Stn6 & 27.7 & 0.09 & 3.5 & 1.0 & 15.5 & 4.1 & 11.9 & -29.5 & 6.1 \\
\hline $\operatorname{Stn} 7$ & 27.4 & 0.09 & 4.1 & 6.0 & 29.9 & 3.4 & 8.8 & -29.5 & 6.3 \\
\hline $\operatorname{Stn} 8$ & 28.3 & 0.06 & 2.9 & 6.5 & 30.6 & 3.8 & 8.1 & -28.5 & 6.0 \\
\hline Mean & $27.7 \pm 0.3$ & $5.7 \pm 7.5$ & $9.6 \pm 6.9$ & $3.8 \pm 2.1$ & $48.8 \pm 36$ & $4.8 \pm 2.0$ & $10.8 \pm 5.1$ & $-28.4 \pm 2.2$ & $12.8 \pm 10$ \\
\hline \multicolumn{10}{|c|}{ Pre-monsoon season } \\
\hline Stn1 & 30.8 & 34.58 & 7.2 & 9.2 & 40.6 & 7.7 & 5.3 & -24.8 & 20.3 \\
\hline $\operatorname{Stn} 2$ & 30.9 & 34.06 & 8.6 & 6.3 & 44.2 & 8.7 & 5.1 & -22.0 & 24.2 \\
\hline
\end{tabular}




\begin{tabular}{lccccccccc} 
Stn3 & 30.7 & 33.86 & 10.8 & 5.8 & 57.8 & 10.7 & 5.4 & -23.8 & 17.1 \\
Stn4 & 30.8 & 32.65 & 7.3 & 14.7 & 86.0 & 14.1 & 6.1 & -29.6 & 24.3 \\
Stn5 & 31.5 & 30.19 & 8.8 & 14.0 & 64.1 & 14.3 & 4.5 & -23.2 & 33.6 \\
Stn6 & 31.5 & 29.13 & 10.9 & 13.9 & 74.1 & 15.3 & 4.8 & -22.4 & 42.1 \\
Stn7 & 31.3 & 24.44 & 14.1 & 11.0 & 65.3 & 13.9 & 4.7 & -22.4 & 22.8 \\
Stn8 & 31.2 & 21.33 & 7.6 & 17.2 & 85.1 & 15.0 & 5.7 & -21.1 & 19.8 \\
Stn9 & 31.8 & 17.46 & 6.3 & 9.3 & 71.7 & 14.0 & 5.1 & -24.4 & 41.5 \\
Mean & $\mathbf{3 1 . 2} \pm \mathbf{0 . 4}$ & $\mathbf{2 8 . 6} \pm \mathbf{6 . 2}$ & $\mathbf{9 . 1} \pm \mathbf{2 . 5}$ & $\mathbf{1 1 . 3} \pm \mathbf{3 . 9}$ & $\mathbf{6 5 . 4} \pm \mathbf{1 6}$ & $\mathbf{1 2 . 6} \pm \mathbf{2 . 8}$ & $\mathbf{5 . 2} \pm \mathbf{0 . 5}$ & $\mathbf{- 2 3 . 7} \pm \mathbf{2 . 5}$ & $\mathbf{2 7 . 3} \pm \mathbf{9 . 4}$ \\
\hline
\end{tabular}


Table 2

Distribution of D-amino acid, mol \% D-amino acids to THAA, D- amino acid normalized carbon and nitrogen yields and Bacterial carbon and nitrogen contribution at various sampling stations during the monsoon and pre-monsoon season in the Mandovi estuary

\begin{tabular}{|c|c|c|c|c|c|c|c|c|c|c|c|c|}
\hline \multirow[t]{2}{*}{ Stations } & \multirow{2}{*}{$\begin{array}{l}\text { D-AA } \\
(n M)\end{array}$} & \multirow{2}{*}{$\begin{array}{l}\text { D-AA }^{a} \\
(\operatorname{mol} \%)\end{array}$} & D-Glu & D-Ala & D-Asp & D-Ser & \multirow[t]{2}{*}{ D-Glu } & D-Ala & D-Asp & \multirow[t]{2}{*}{ D-Ser } & \multicolumn{2}{|c|}{ Bacterial } \\
\hline & & & \multicolumn{4}{|c|}{ nmol mg C $\mathbf{C}^{-1}$} & & \multicolumn{2}{|c|}{ nmol mg $\mathrm{N}^{-1}$} & & \multirow[t]{2}{*}{$\% \mathrm{C}$} & \multirow[t]{2}{*}{$\% \mathbf{N}$} \\
\hline Monsoon & season & & & & & & & & & & & \\
\hline Stn1 & 25.3 & 1.2 & 11.1 & 5.7 & 1.8 & 0.9 & 208.7 & 107.6 & 34.4 & 17.5 & 16.4 & 70.2 \\
\hline Stn2 & 20.1 & 1.1 & 10.4 & 14.5 & 1.7 & 1.7 & 67.8 & 94.1 & 11.2 & 11.2 & 23.6 & 34.6 \\
\hline $\operatorname{Stn} 3$ & 22.0 & 1.7 & 9.1 & 6.8 & 2.2 & 0.6 & 101.1 & 75.0 & 23.9 & 7.1 & 16.0 & 40.0 \\
\hline Stn 4 & 14.5 & 2.2 & 15.0 & 22.7 & 2.3 & 1.4 & 74.9 & 113.1 & 11.7 & 7.1 & 24.1 & 29.1 \\
\hline $\operatorname{Stn} 5$ & 9.0 & 2.1 & 16.5 & 18.3 & 1.0 & 2.2 & 133.3 & 147.6 & 8.2 & 17.7 & 21.6 & 42.2 \\
\hline Stn6 & 9.7 & 11.5 & 17.2 & 33.3 & 0.2 & 1.3 & 175.3 & 340.1 & 2.2 & 13.2 & 30.5 & 75.5 \\
\hline $\operatorname{Stn} 7$ & 20.9 & 4.1 & 33.7 & 22.9 & 0.1 & 1.4 & 254.2 & 172.9 & 1.1 & 10.3 & 34.3 & 62.4 \\
\hline Stn8 & 11.1 & 5.2 & 7.5 & 21.2 & 0.1 & 1.4 & 52.1 & 146.4 & 0.9 & 9.8 & 17.4 & 29.1 \\
\hline Mean & $16.6 \pm 6.3$ & $3.6 \pm 3.5$ & $15.1 \pm 8.3$ & $18.2 \pm 9.1$ & $1.2 \pm 0.9$ & $1.4 \pm 0.5$ & $133.4 \pm 73.1$ & $149.6 \pm 83.3$ & $11.7 \pm 12$ & $11.7 \pm 4.1$ & $23.0 \pm 6.7$ & $47.9 \pm 18.7$ \\
\hline
\end{tabular}




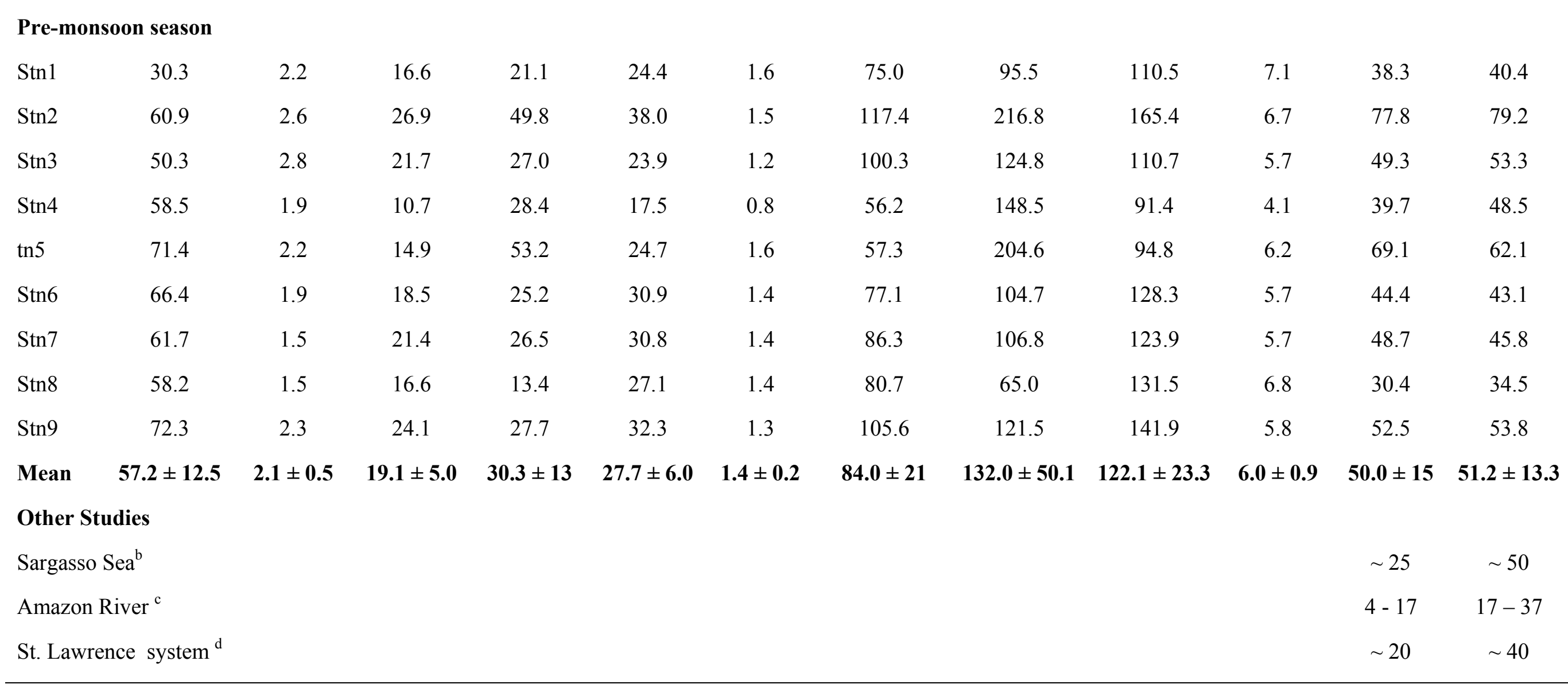

D-AA ${ }^{\mathrm{a}}=$ D-AA X 100/ THAA

Sargasso Sea ${ }^{\mathrm{b}}$ : Kaiser and Benner 2008; Amazon River ${ }^{\mathrm{c}}$ : Tremblay and Benner, 2009; St. Lawrence system ${ }^{\mathrm{d}}$ : Bourgoin and Tremblay, 2010. 